\title{
IDENTIFIKASI POTENSI PARIWISATA BUDAYA DI KAMPUNG ADAT PRAI IJING, KECAMATAN KOTA WAIKABUBAK, SUMBA BARAT NTT
}

\author{
Fatrisia Yulianie $^{1}$, Fransiska Fila Hidayana ${ }^{2}$ \\ Institut Pariwisata dan Bisnis Internasional ${ }^{1}$ \\ Email: fatrisiayulianie85@gmail.com \\ Akademi Pariwisata Denpasar ${ }^{2}$ \\ Email: filahidayana@akpar-denpasar.ac.id
}

\author{
Received: July 11, 2020 | Accepted: August 26, 2020 | Published: Nov. 2, 2020 \\ Permalink/DOI: https://doi.org/10.53356/diparojs.v1i1.14
}

\begin{abstract}
ABSTRAK
Artikel ini bertujuan untuk membahas perkembangan pariwisata dan identifikasi potensi wisata budaya di Kampung Adat Prai Ijing, Kecamatan Kota Waikabubak, Sumba Barat, Nusa Tenggara Timur. Pengumpulan data dilakukan dengan observasi, wawancara, dan dokumentasi. Teknik pengambilan sampel adalah purposive sampling. Data dianalisis dengan menggunakan analisis deskriptif kualitatif untuk memberikan gambaran umum mengenai identifikasi potensi wisata budaya di Kampung Adat Prai Ijing. Hasil analisis menunjukkan bahwa Kampung Adat Prai Ijing merupakan salah satu tujuan wisata potensial dengan kuburan megalitik dan rumah tradisional didalamnya dan memiliki budaya yang unik, lokasi yang strategis, dan dikunjungi oleh wisatawan. Pengembangan pariwisata dikelola oleh Bumdes Iyya Tekki dan melibatkan masyarakat desa. Pengembangan ini mampu memberikan penghasilan tambahan bagi masyarakat setempat. Upaya yang dilakukan untuk meningkatkan kualitas sumber daya manusia dengan pelatihan keterampilan dan bahasa Inggris. Adapun komponen pariwisata dalam mendukung pengembangan pariwisata, yaitu atraksi, aksesibilitas, fasilitas, dan keberadaan lembaga manajemen. Sebagai masukan untuk pengembangan lebih lanjut, perlunya memelihara kelestarian budaya dan kearifan lokal, meningkatkan kualitas pelayanan, keragaman atraksi dan kegiatan wisata di Kampung Adat Prai Ijing.
\end{abstract}

Kata kunci: Identifikasi, potensi, wisata budaya, desa tradisional

\begin{abstract}
This article is about a cultural tourism in the Prai Ijing Traditional Village, Waikabubak City District, West Sumba, East Nusa Tenggara. The aim of this article is to discuss the tourism development and identify the potential of cultural tourism in the Prai Ijing Traditional Village, Waikabubak City District, West Sumba, East Nusa Tenggara. The data were collected by observation, interviews, and documentation. The sampling techniques were purposive sampling. The data were analyzed using descriptive qualitative analysis to give an overview of the identity of the potential of cultural tourism in the Prai Ijing Traditional Village. The results of the analysis show that The Traditional Village of Prai Ijing is one of the potential tourist destinations with a megalithic grave bed and traditional house inside having a unique culture, a strategic location, and having been visited by tourists. The tourism development is managed by Bumdes Iyya Tekki and the entire village community. The development is able to provide additional income for th local community. There are efforts to improve the quality of human resources through skill training and english class. There are tourism components in supporting tourism development, namely attractions, accessibility, amenities, and the existence of a management institution (ancillary). As input for further development, it is necessary to maintain the cultural preservation and local wisdom, improve the service quality, the diversityof attractions and tourist activities in Prai Ijing Traditional Village
\end{abstract}

Keywords: Identification, potential, cultural tourism, traditional village 


\section{PENDAHULUAN}

Kebudayaan merupakan salah satu aset pariwisata yang menjadi daya tarik pariwisata didalamnya terdapat berbagai macam tradisi, kesenian, perilaku dan arsitektur bangunan yang khas dari suatu daerah. Pariwisata menjadi salah satu faktor penting untuk menggalang rasa persatuan bangsa yang rakyatnya memiliki etnis, dialek, adat isitiadat, dan cita rasa yang beraneka ragam. Pariwisata menjadi suatu manifestasi lintas budaya yang penting, karena kegiatan ini menjadi kancah pertemuan warga dari berbagai bangsa, yang latar belakang budayanya berbeda dan lingkungan sosial yang beragam pula, sebagaimana yang kini terjadi pada pengembangan destinasi wisata pada satu pulau di provinsi Nusa Tenggara Timur yaitu Pulau Sumba.

Pulau Sumba merupakan salah satu pulau yang terletak di bagian barat daya pulau Timor Provinsi Nusa Tenggara Timur (NTT). Pulau Sumba terkenal dengan padang savana, atraksi budaya Pasola, dan perkampungan tradisional yang masih asli. Kabupaten Sumba Barat merupakan salah satu kabupaten yang berada di Provinsi Nusa Tenggara Timur yang memiliki kekayaan alam dan budaya yang unik, Ibukota Kabupaten Sumba Barat adalah Waikabubak. Secara administratif Sumba Barat mempunyai luas wilayah administratif seluas: $2.183,18 \mathrm{~km} 2$ yang terdiri dari 6 kecamatan, 11 kelurahan dan 49 desa.

Keeksotisan Sumba Barat tidak lepas dari pesona alam dan budaya yang mengelilingi Kabupaten Sumba Barat yang mampu menjadi daya tarik bagi wisatawan nusantara maupun mancanegara untuk berkunjung ke Sumba Barat. Budaya yang lekat dengan Sumba Barat tetap lestari hingga sekarang. Terdapat beberapa kampung adat, atau permukiman adat Sumba Barat yang sering dikunjungi oleh wisatawan, salah satunya Kampung Adat Prai Ijing.

Kampung Adat Prai Ijing terletak di Dusun Prai Ijing Desa Tebara, Kecamatan Kota Waikabubak, Kabupaten Sumba Barat, Provinsi Nusa Tenggara Timur (NTT). Kampung Adat Prai Ijing merupakan salah satu destinasi wisata potensial dengan hamparan batu kubur megalitikum dan rumah adat tradisional didalamnya serta memiliki budaya yang unik, lokasi strategis, serta ramai dikunjungi wisatawan. Kampung adat ini telah ditetapkan oleh Pemerintah Desa Tebara sebagai daya tarik wisata (Perdes Tebara No. 2 Tahun 2018 tentang Daftar Kewenangan Berdasarkan Hak Asal Usul dan Kewenangan Lokal Berskala Desa) dan dikelola secara profesional oleh Bumdes Iyya Tekki Desa Tebara.

Berdasarkan latar belakang di atas, maka rumusan masalah dalam artikel ini adalah: bagaimana perkembangan kepariwisataan di Kampung Adat Prai Ijing, Desa Tebara; dan apa saja komponen pariwisata yang terdapat di Kampung Adat Prai Ijing dalam pengembangan pariwisata di daya tarik wisata tersebut.

\section{KAJIAN LITERATUR \\ 2.1 Pengembangan Wisata}

Dalam pengembangan pariwisata baik yang masih berupa potensi maupun yang berupa objek dan daya tarik wisata yang sudah ada harus sesuai dengan kriteria-kriteria pengembangan pariwisata. Menurut Grady dalam Suwantoro (2002:50), ada beberapa kriteria sebagai arahan yang lebih jelas dalam pengembangan pariwisata yaitu :

a. Decision making about the form of tourism in any place must be made 
in consultation with the local people and be acceptable to them.

b. A reasonable share of the profits derived from tourism must be return to the people.

c. Tourism must be based on sound environmental and ecological principles, be sensitive to local cultural and religious traditions and should not place any members of the host community in a position of inferiority.

d. The numbers of tourism visiting an area should not be such that they over shelm the local population and deny possibility of genuine human encounter.

Pengambilan

keputusan mengenai bentuk pengembangan pariwisata di setiap tempat harus dilakukan dengan berkonsultasi dengan masyarakat lokal dan dapat diterima oleh masyarakat lokal tersebut. Hal ini dilakukan agar pengembangan pariwisata tersebut dapat berjalan dengan lancar, tidak mendapat halangan dari masyarakat lokal. Tanpa dukungan dari masyarakat lokal maka mustahil pengembangan pariwisata akan berjalan sesuai dengan yang direncanakan.

Sebagian keuntungan yang diperoleh dari pengembangan pariwisata akan diberikan kepada masyarakat lokal. Artinya, pengembangan pariwisata diharapkan dapat memberikan manfaat ekonomi bagi masyarakat lokal yang nantinya dapat dimanfaatkan untuk memenuhi kebutuhan hidupnya dan juga untuk menjaga kelestarian sumber daya yang ada.

Bentuk pariwisata yang dikembangkan tersebut harus didasarkan pada prinsip-prinsip lingkungan dan ekologis, peka terhadap tradisi budaya dan agama setempat dan tidak harus menempatkan setiap anggota masyarakat tuan rumah dalam posisi inferiory. Pariwisata dikembangkan sesuai dengan daya dukung lingkungan yang dimiliki agar tidak menmbulkan kerusakan lingkungan. Selain itu, kegiatan pariwisata yang dikembangkan menghargai tradisi budaya dan agama setempat agar tidak menimbulkan kesalahpahaman di antara pihak pengembang dan masyarakat lokal. Dalam pengembangan pariwisata, masyarakat lokal perlu dilibatkan dan setiap proses pengembangan. Keterlibatan ini tentunya disesuaikan dengan keahlian dan keterampilan sumber daya manusia yang ada di daerah tersebut.

Jumlah kunjungan wisatawan dalam suatu area tidak harus melebihi penduduk lokal dan menyangkal kemungkinan pertemuan dengan masyarakat asli setempat. Jumlah kunjungan wisatawan ke suatu area harus disesuaikan dengan daya dukung lingkungan, sehingga diperlukan batasan-batasan jumlah pengunjung agar tidak merusak lingkungan di sekitar area pariwisata. Bentuk pariwisata yang dikembangkan tidak membatasi interaksi antara wisatawan dan masyarakat lokal. Sehingga dengan demikian akan terjadi interaksi yang baik di antara kedua belah pihak.

Dapat

disimpulkan pengembangan pariwisata yang dimaksud dalam penelitian ini adalah pengembangan pariwisata yang dapat diterima dan didukung oleh masyarakat lokal, dikembangkan berdasarkan prinsip-prinsip lingkungan dan ekologis, peka terhadap tradisi budaya dan agama setempat, serta dapat memberikan manfaat bagi masyarakat lokal khususnya masyarakat Kampung Adat Prai Ijing, Kecamatan Kota 
Waikabubak, Kabupaten Sumba Barat, NTT.

\subsection{Daya Tarik Wisata}

Undang-Undang RI Nomor 10 Tahun 2009 tentang Kepariwisataan menyebutkan bahwa daya tarik wisata adalah segala sesuatu yang memiliki keunikan, keindahan, dan nilai yang berupa keanekaragaman kekayaan alam, budaya, dan hasil buatan manusia yang menjadi sasaran atau tujuan kunjungan wisatawan.

Menurut Yoeti (1996:178), suatu daerah tujuan wisata hendaknya memenuhi beberapa syarat, yaitu:

a. Ketersediaan sesuatu yang dapat dilihat (something to see). Artinya, di tempat tersebut harus ada daya tarik yang berbeda dengan apa dimiliki daerah lain.

b. Sesuatu yang dapat dilakukan (something to do). Artinya, di tempat tersebut selain banyaki yang dapat dilihat dan disaksikan, harus pula disediakan fasilitas rekreasi yang dapat membuat mereka betah tinggal lebih lama di tempat itu.

c. Sesuatu yang dapat dibeli (something to buy). Artinya, di tempat tersebut harus tersedia fasilitas untuk berbelanja terutama barang-barang souvenir dan kerajinan rakyat sebagai oleh-oleh untuk dibawa pulang ke tempat asal masing-masing.

Menurut Yoeti (2006:167), secara garis besar terdapat empat kelompok yang merupakan daya tarik bagi wisatawan datang pada suatu negara daerah tujuan wisata tertentu, yaitu: natural attraction, build attraction, cultural attraction, dan social attraction.

a. Natural Attraction, termasuk dalam kelompok ini adalah pemandangan alam, laut, pantai, danau, air terjun, kebun raya, agrowisata, gunung berapi, serta flora dan fauna.

b. Build Attraction, termasuk dalam kelompok ini adalah bangunan dengan arsitektur yang menarik, seperti rumah adat, bangunan kuno dan bangunan modern.

c. Cultural Attraction, dalam kelompok ini termasuk diantaranya peninggalan sejarah (historical building), cerita-cerita rakyat (folklore), kesenian tradisional, museum, upacara keagamaan, festival kesenian dan semacamnya.

d. Social Attraction, yang termasuk kelompok ini adalah tata cara hidup suatu masyarakat (the way of life), ragam bahasa (languages), upacara perkawinan, upacara potong gigi, khitanan dan kegiatan sosial lainnya. Wisatawan yang melakukan perjalanan wisata ke daerah tujuan wisata memerlukan berbagai kebutuhan dan pelayanan mulai dari keberangkatan sampai kembali lagi ke tempat tinggalnya. Aktivitas pariwisata sangat terkait dengan kehidupan kita sehari-hari. Sama seperti yang dilakukan setiap hari, wisatawan juga membutuhkan makanan dan minuman, tempat menginap, serta alat transportasi yang membawanya pergi dari suatu tempat ke tempat lainnya. Menurut Cooper dalam Suwena (2010:88), untuk memenuhi kebutuhan dan pelayanan tersebut, daerah tujuan wisata harus didukung empat komponen utama atau yang dikenal dengan istilah "4A" yaitu: Attraction (atraksi), Accessibility (aksesibilitas), Amenities (fasilitas), dan Ancillary Services (pelayanan tambahan).

Daya tarik wisata yang dimaksud dalam penelitian ini adalah sebuah kampong adat yang memiliki keunikan, keindahan, dan nilai yang berupa keanekaragaman kekayaan alam, budaya, dan 
hasil buatan manusia yang menjadi sasaran atau tujuan kunjungan wisatawan ke Kecamatan Kota Waikabubak, Kabupaten Sumba Barat, NTT.

\subsection{Kampung Adat}

Menurut Pitana dan Nehen (dalam Fitriyani, 2016) pengertian kampung adalah desa, dusun atau kelompok rumah-rumah yang merupakan bagian kota yang mengacu kepada kelompok tradisional dengan dasar ikatan adat istiadat. Kampung adat merupakan suatu komunitas tradisional dengan fokus fungsi dalam bidang adat dan tradisi, dan merupakan satu kesatuan wilayah di mana para anggotanya secara bersamasama melaksanakan kegiatan sosial dan tradisi yang ditata oleh suatu sistem budaya. Selanjutnya, dengan mengacu kepada berbagai batasan yang diberikan terhadap kampung adat, disimpulkan ciri-ciri kampung adat sebagai berikut:

a. Mempunyai batas-batas tertentu yang jelas. Umumnya berupa batas alam, seperti sungai, hutan, jurang, bukit, atau pantai.

b. Mempunyai anggota dengan persyaratan tertentu.

c. Mempunyai rumah adat yang mempunyai fungsi dan peranan.

d. Mempunyai otonomi, baik ke luar maupun ke dalam.

e. Mempunyai suatu pemerintahan adat, dengan kepengurusan (prajuru adat)

sendiri.

Dari penjelasan konsep kampung adat tersebut kampung adat yang dimaksud dalam artikel ini adalah kampung, dusun atau kelompok rumah-rumah yang merupakan bagian kota yang mengacu kepada kelompok komunitas tradisional dengan ikatan adat istiadat dan tradisi dalam satu kesatuan wilayah Kampung Adat Prai Ijing di mana para anggotanya secara bersama-sama melaksanakan kegiatan sosial dan tradisi yang ditata oleh suatu sistem budaya.

\subsection{Pariwisata Budaya}

Pariwisata budaya dapat didefinisikan secara sempit dan luas. Dalam pengertian sempit, pariwisata budaya menyangkut perpindahan orang sematamata karena motivasi budaya seperti: berpergian untuk studi, melihat seni pertunjukkan dan budaya, mengunjungi festival, mengunjungi monument dan peninggalan purbakala, mengunjungi kesenian rakyat, dan perjalanan (berziarah) ke tempat suci. Di sisi lain, dalam pengertian yang lebih luas, pariwisata budaya menyangkut semua perpindahan orang yang bertujuan untuk memenuhi kebutuhan akan sesuatu yang berbeda, mempertinggi tingkat budaya seseorang, memberi pengetahuan dan pengalaman (Lim dalam Ardika 2007: 32)

Menurut Lester Borley (Ardika 2007: 32) menyatakan bahwa pariwisata budaya merupakan aktivitas yang memungkinkan wisatawan untuk mengetahui dan memperoleh pengalaman tentang perbedaan cara hidup orang lain, merefleksikan adat-istiadatnya, tradisi religiusnya, dan ide-ide intelektual yang terkandung dalam warisan budaya yang belum dikenalnya.

Pariwisata budaya yang dimaksud dalam artikel ini adalah kegiatan wisata yang dilakukan dengan mengunjungi salah satu warisan budaya Kabupaten Sumba Barat yang memiliki nilai sejarah dan arsitektur yang tinggi dengan tujuan untuk memperoleh pengalaman dan pengetahuan mengenai adat istiadat Kampung Adat Prai Ijing, Kecamatan Kota Waikabubak, Kabupaten Sumba Barat, NTT. 


\section{METODE PENELITIAN}

Artikel ini menggunakan metode deskriptif kualitatif yang berusaha mendeskripsikan/menggambarkan/melukiskan fenomena atau hubungan antar fenomena yang diteliti dengan sistematis, faktual dan akurat (Kusmayadi, 2000:29). Jenis data yang dikumpulkan adalah data kualitatif yang berupa kalimat atau uraian dan data kuantitatif yang berupa angka-angka. Sumber data yang digunakan adalah sumber data primer dan data sekunder. Sumber data primer yaitu yang bersumber langsung dari informan. Sedangkan data sekunder yaitu yang bersumber dari pihak lain atau bukan dari sumber pertama yang berkaitan dengan penelitian ini. Data yang diperoleh melalui observasi, wawancara mendalam dan studi dokumentasi dianalisis secara deskriptif kualitatif. Penentuan informan dilakukan dengan cara purposive sampling. Penyajian hasil penelitian dilakukan secara naratif sehingga akan diperoleh gambar lebih jelas dan mendalam tentang penelitian yang dilakukan.

\section{PEMBAHASAN}

\subsection{Gambaran Umum}

Desa Tebara merupakan salah satu desa dari tujuh desa yang berada di wilayah Kecamatan Kota Waikabubak dengan jumlah penduduk 590 KK yang terdiri dari enam Dusun, 12 RT, enam RW. Desa Tebara terletak di sebelah timur Desa Kodaka, pada tahun 1965 dipimpin oleh Y. B.Kaleka dan kemudian membentuk enam lingkungan atau dusun. Hal ini berdasarkan kesepakatan antara Pemerintah Daerah Kabupaten Sumba Barat, tokoh masyarakat, dan juga anggota masyarakat.
Kampung Adat Prai Ijing terletak di Dusun Prai Ijing Desa Tebara, Kecamatan Kota Waikabubak, Sumba Barat. Kampung ini dihuni oleh 636 jiwa penduduk. Kampung Adat Prai Ijing diperkirakan berumur 180an tahun, dilihat dari sejarah nenek moyang. Kampung Adat Prai Ijing masih mempertahankan adat leluhur dengan memberi nama anak dari nama kakek atau neneknya untuk mengetahui garis keturunan ke berapa. Dari garis keturunan tersebut dapat diperkirakan umur dari Kampung Adat Prai Ijing. Prai Ijing berasal dari bahasa Sumba Barat prai yang berarti kampung dan ijing yang berarti buah kedondong hutan. Nenek moyang tidak hanya berasal dari Kampung Adat Prai Ijing saja tetapi juga berasal dari daerah lain di Sumba yang terdiri dari 22 kabihu (garis keturunan keluarga besar, clan).

Kabihu atau kabisu merupakan garis keturunan terdiri dari beberapa uma yang berasal dari seorang nenek moyang dan antara satu dengan lainnya terikat melalui garis keturunan laki-laki saja. Uma yaitu kelompok kekerabatan yang terdiri dari satu keluarga inti senior ditambah dengan keluarga-keluarga inti dari anak laki-lakinya. Mereka berdiam dalam satu rumah besar yang disebut uma juga. Keberadaan kabisu berfungsi dalam mengatur upacara perkawinan, upacara kematian, upacara sebelum menanam padi, upacara panen, mengatur hal-hal yang boleh dan tidak boleh dilakukan, menceritakan sejarah asal usul, dan segala macam urusan sosial lainnya.

Kampung Adat Prai Ijing dulunya memiliki 42 rumah. Namun pada tahun 2000, mengalami kebakaran sehingga yang masih bertahan dan dapat diselamatkan kembali tersisa 38 rumah adat. Rumah-rumah adat terlihat unik dan mencolok yaitu barisan rumah adat 
dengan atap menara yang menjulang tinggi. Filosofi rumah menara artinya menjelaskan pemujaan terhadap sang pencipta. Walaupun tidak semua atap dilengkapi dengan menara. Rumah yang dilengkapi atap menara disebut dengan Uma Mbatangu, sedangkan yang tidak dilengkapi menara disebut dengan Uma Bokulu atau rumah besar, atapnya tidak seperti menara. Uma Mbatangu tinggi atapnya bisa mencapai 30 meter. Kedua jenis rumah ini adalah rumah panggung terbuat dari kayu malela, kayu mata api dan kayu nangka dengan atap dari alangalang. Rumah adat terbagi 3 bagian, bagian bawah untuk memelihara ternak, bagian tengah untuk manusia beraktivitas dan bagian atas untuk menyimpan makanan dan juga benda pusaka. Tiga tingkatan ini memiliki filosofi bahwa tingkat paling bawah yaitu kehidupan manusia di bumi, tingkat kedua ada perapian di tengah rumah untuk penyucian, dan tingkat ketiga yaitu menara merupakan pemujaan kepada Sang Pencipta. Bagian atas ini juga diyakini sebagai tempat roh. Selain rumah adat, di Kampung Adat Prai Ijing juga terdapat batu kubur di depan rumah yang menjelaskan konsep kelahiran dan kematian bahwa manusia harus ingat ketika dia lahir suatu saat pasti akan mati, keniscayaan kematian bahwa kematian adalah kepastian.

\subsection{Perkembangan Kepariwisataan di}

Kampung Adat Prai Ijing,
Desa Tebara

Geliat pariwisata di Kampung Adat Prai Ijing tidak lepas dari peran Kepala Desa Tebara, Marthen Ragowino B. Ketika kembali dari menempuh pendidikan di Yogyakarta pada tahun 2007, dengan beberapa orang anak muda menggagas untuk mengembangkan Kampung Adat Prai Ijing karena ramainya kunjungan wisatawan baik nusantara maupun mancanegara. Pada saat itu retribusi tiket masih secara manual, yaitu dengan menggunakan buku tamu, kemudian berinteraksi dengan wisatawan, menuliskan harapan pada buku tamu tersebut berharap bantuan wisatawan yang datang, di mana donasi tersebut digunakan untuk operasional dalam menjaga kelestarian kampung. Berjalan selama lima tahun, tingkat kunjungan wisatawan ke Kampung Adat Prai Ijing semakin meningkat. Pada tahun 2012 Marthen bersama beberapa pemuda kampung berupaya meningkatkan partisipasi masyarakat Kampung Adat Prai Ijing untuk terlibat menjadi pelaku pariwisata, walaupun pada awalnya banyak menemui kendala. Seperti ketidaksiapan masyarakat, tidak mengerti pariwisata. Namun seiring berjalannya waktu karena setiap hari dikunjungi wisatawan, diajak berinteraksi dengan wisatawan, selalu dilibatkan dalam musyarawarah dan bertukar pikiran sehingga akhirnya masyarakat paham mengenai pentingnya pengembangan pariwisata di kampung mereka, namun tetap memperhatikan kearifan lokal Kampung Adat Prai Ijing.

Kampung Adat Prai Ijing resmi ditetapkan sebagai daya tarik wisata pada 2 Juli 2018 berdasarkan Perdes Tebara No. 02 Tahun 2018 tentang Daftar Kewenangan bedasarkan Hak Asal Usul dan Kewenangan Lokal Berskala Desa Pasal 5 Ayat 1 dan Perdes Tebara No. 04 Tahun 2018 tentang Retribusi Objek Wisata Desa, Penginapan Desa dan Pasar Desa. Adapun retribusi masuk Kampung Adat Prai Ijing untuk pengunjung wisatawan nusantara Rp. 20.000/orang dan Rp 50.000/orang untuk wisatawan mancanegara.

Perkembangan wisata di Kampung Adat Prai Ijing semakin maju dikelola oleh Bumdes Iyya Tekki, daya tarik 
wisata ini memberikan dampak ekonomi yang besar bagi masyarakat lokal. Pada awal pengembangan Kampung Adat Prai Ijing sebagai daya tarik wisata Pendapatan Asli Desa (PAD) yang diperoleh dari kegiatan wisata mencapai lebih dari Rp. 80.000.000 dalam dua bulan. Ada 60 orang warga Dusun Prai Ijing yang dilibatkan mengurus kegiatan pariwisata yang kebanyakan adalah petani dan buruh ladang. Keberadaan Kampung Adat Prai Ijing ini mampu memberikan tambahan penghasilan bagi masyarakat lokal yang terlibat secara langsung pada kegiatan pariwisata. Selain itu, ramainya tingkat kunjungan wisatawan juga memberikan manfaat ekonomi bagi warga Dusun Prai Ijing secara umum, yang diperoleh dari tiket masuk, maupun dari atraksi dan aktivitas wisata di Kampung Adat Prai I jing, diantaranya menyumbangkan dana bagi warga yang sedang kedukaan (uang kopi gula), pada akhir tahun 2018 membagikan kontribusi sebesar Rp. 500.000/rumah yang digunakan untuk biaya upacara podu (puasa), dan pembayaran listrik sumur bor sebesar Rp. 215.000/bulan. Semakin banyaknya masyarakat Kampung Adat Prai Ijing yang terlibat dalam kegiatan wisata diharapkan pada akhirnya masyarakat menjadi mandiri dan produktif, dana desa hadir menjadi stimulan sehingga hadir usaha-usaha ekonomi produktif di masyarakat. Harapannya dengan adanya pengembangan pariwisata, masyarakat menjadi produktif, sekaligus tetap dapat menjalankan budaya secara professional. Artinya seimbang dengan pendapatan, yaitu tidak lagi dilanda masalah utang piutang atau kemiskinan serta dapat mencukupi kebutuhan rumah tangganya.

Selain membangun sarana dan infrastruktur, Kepala Desa bekerjasama dengan Pemerintah Kabupaten Sumba Barat serta Bumdes Iyya Tekki berupaya meningkatkan kualitas sumber daya manusia dengan mengikutsertakan anakanak dan remaja belajar Bahasa Inggris melalui komunitas English goes to Kampung. Hal ini mengingat pentingnya kemampuan berkomunikasi dengan setiap tamu yang datang. Kegiatan ini dilaksanakan setiap dua kali seminggu sejak April 2018. Kemampuan dan keterampilan berbahasa Inggris para pelajar usia SD hingga SMA terus dilatih agar kelak mereka mampu menjadi generasi penerus kegiatan wisata di Kampung Adat Prai Ijing, termasuk menjadi pemandu wisata. Hal ini merupakan upaya dalam meningkatkan pelayanan serta keramahtamahan masyarakat lokal dalam menyambut dan melayani tamu yang datang. Keramahan warga menjadi salah satu magnet kuat untuk menarik wisatawan yang datang.

Pengembangan kawasan ini menggunakan Rp. 150.000 .000 dari total dana desa sekitar Rp. 1,2 Milyar dari Pemerintah Pusat melalui Kementrian Desa, Pembangunan Daerah Tertinggal dan Transmigrasi melalui Program Kotaku (Kota Tanpa Kumuh). Diantaranya untuk melakukan penataan, pembangunan rumah adat, tempat sampah, toilet, dan penataan pagar keliling kampung.

Upaya peningkatan kualitas sumber daya manusia, khususnya di bidang pariwisata dilakukan juga dengan melaksanakan pelatihan keterampilan secara rutin. Kampung Adat Prai Ijing merupakan salah satu desa binaan wisata Balai Latihan Masyarakat (BLM) Denpasar. Pelatihan berupa pembuatan kerajinan tangan yang terbuat dari bahan alami yang berasal dari tanaman-tanaman hasil alam dan hewan khas Sumba, 
khususnya Kampung Adat Prai Ijing, seperti tas yang terbuat dari daun pandan, gelas bambu, gantungan kunci dan mangkok dari tempurung kelapa, kalung parang terbuat dari tanduk kerbau, mamuli/hiasan terbuat dari tanduk kerbau, tas manik khas Kampung Adat Prai Ijing. Selain itu, perangkat desa, anggota Bumdes, serta masyarakat yang terlibat dalam kegiatan wisata di Kampung Adat Prai Ijing juga secara rutin mengikuti pelatihan sumber daya manusia atau studi banding ke luar kota, seperti ke Bali dan Yogyakarta dengan harapan memperoleh ilmu dan keterampilan yang kemudian dapat diaplikasikan dalam mengelola dan mengembangkan Kampung Adat Prai Ijing secara berkelanjutan, yaitu tidak hanya terfokus pada pengembangan atraksi, produk dan aktivitas wisata tapi juga mengutamakan pelayanan yang profesional dengan selalu menjaga kelestarian dan kearifan lokal Kampung Adat Prai Ijing.

\subsection{Atraksi, Akesesibiltas, Amenitas} dan Lembaga Pengelola (Ancilarry) di Kampung Adat Prai Ijing, Desa

\section{Tebara}

Komponen pariwisata dalam menunjang pengembangan pariwisata di Kampung Adat Prai Ijing, terdiri dari 4 komponen sebagai berikut:

\section{a. Atraksi}

Kampung Adat Prai Ijing merupakan salah satu destinasi wisata potensial yang terdapat di Kabupaten Sumba Barat dengan hamparan batu kubur megalitikum dan rumah adat tradisional di dalamnya. Letak kampung yang strategis persis di atas bukit Prai Ijing menambah suasana eksotis, sehingga wisatawan dapat leluasa menikmati pemandangan dengan panorama alam yang masih alami dengan hamparan persawahan. Dari kampung ini pula dapat melihat bentangan Kota Waikabubak, ibukota Kabupaten Sumba Barat.

Wisatawan dapat melakukan berbagai aktivitas di kampung adat ini yaitu mengambil foto di spot foto yang telah disediakan, foto mengenakan pakaian khas tradisional Sumba Barat, melihat kuburan megalitik, memperoleh penjelasan dari pemandu wisata mengenai sejarah dan filosofi arsitektur rumah adat maupun kubur batu. Selain pertunjukkan seni, Kampung Adat Prai Ijing memiliki daya tarik kehidupan penduduk yang masih tradisional dengan bangunan rumah-rumah adat yang memesona. Wisatawan dapat melihat secara langsung proses pembuatan kain tenun ikat khas Sumba Barat dan apabila berminat dapat membeli kain tenun hasil tenunan masyarakat kampung sebagai souvenir atau oleh-oleh.

Kampung Adat Prai Ijing juga menawarkan beberapa atraksi dan aktivitas pilihan kepada wisatawan dengan dikenakan biaya tambahan selain tiket masuk. Diantaranya menyaksikan pertunjukkan tarian tradisional, seperti tari Woleka, Kataga, dan Pajura. Kampung Adat Prai Ijing juga menyediakan atraksi berkuda seperti Pasola. Sebuah atraksi yang menggambarkan adu keperkasaan pria di Sumba yang saling serang dengan menggunakan lembing. Selain itu, bagi wisatawan yang ingin merasakan suasana tradisional dan interaksi lebih dekat dengan masyarakat kampung, pengelola juga menyediakan paket wisata menginap di rumah penduduk. Wisatawan akan dilayani secara tradisional, yaitu diajak terlibat dalam rutinitas masyarakat sehari-hari, seperti menenun, bertani, naik kuda, bermain permainan tradisional dengan anak-anak 
kampung, dan juga berkesempatan untuk memasak dan menikmati masakan tradisional rowekariwa (bahan dasar daun labu, jagung, tepung) sesuai dengan ciri khas Kampung Adat Prai Ijing.

\section{b. Aksesibilitas}

Aksesiblitas merupakan sarana dan infrastruktur yang memberikan kemudahan kepada wisatawan untuk mencapai Kampung Adat Prai Ijing. Faktor-faktor yang terkait dengan aspek aksesibilitas wisata meliputi petunjuk arah, bandara/terminal, waktu yang dibutuhkan, dan transportasi menuju lokasi wisata. Akses menuju Sumba Barat dapat dijangkau melalui Bandar Udara Tambolaka yang terletak di Sumba Barat Daya dengan menggunakan pesawat komersil seperti, Wings Air, Nam Air dan Garuda Indonesia (tipe ATR).

Lokasi Kampung Adat Prai Ijing relatif mudah dijangkau, berjarak tiga kilometer atau hanya membutuhkan waktu tempuh 15 menit dari pusat Kota Waikabubak. Akses menuju Kampung Adat Prai Ijing saat ini tergolong baik, yaitu telah tersedia papan penunjuk arah, jalan menuju kampung sudah beraspal dan untuk mencapainya para wisatawan dapat menggunakan angkutan umum, kendaraan pribadi atau transportasi yang disediakan oleh agen perjalanan. Selain karena keunikan budayanya, lokasi strategis ini menjadikan Kampung Adat Prai Ijing ramai dikunjungi oleh wisatawan.

\section{c. Amenitas}

Beberapa fasilitas pendukung untuk menunjang kegiatan pariwisata di Kampung Adat Prai Ijing, meliputi loket tiket, jalan beraspal, taman, peta pariwisata (tourist map) Kampung Adat Prai Ijing, toilet, gazebo/bale, kios cinderamata, dan lahan parkir yang luas.
Tersedia area parkir kendaraan pengunjung yang berada tepat di bagian depan pintu masuk Kampung Adat Prai Ijing. Lahan parkir yang disediakan cukup luas sehingga motor, mobil maupun bus pariwisata dapat parkir dengan aman dan nyaman.

Lokasi loket tiket terletak di jalan masuk sebelah barat Kampung Adat Prai Ijing, di mana jalan sebelah timur digunakan sebagai jalan keluar masuk penduduk kampung. Setiap hari ada empat orang petugas loket tiket yang bekerja secara bergiliran, dari jam 07.00-17.00. Selain mengatur penjualan tiket masuk kepada wisatawan, petugas loket tiket juga bertanggung jawab dalam melayani kebutuhan wisatawan selama berada di Kampung Adat Prai Ijing, seperti menjadi pemandu wisata, menyediakan pakaian adat bagi wisatawan yang ingin berfoto dengan kostum adat Sumba Barat, serta bekerjasama dengan pengelola dan masyarakat kampung dalam melayani permintaan wisatawan mengenai atraksi dan aktivitas tambahan.

Jalan beraspal dari lahan parkir menuju kampung sepanjang kurang lebih $200 \mathrm{~m}$, memudahkan wisatawan mencapai kampung hanya dengan berjalan kaki. Taman bunga di sebelah kanan jalan dilengkapi dengan meja dan kursi dapat menjadi alternatif tempat duduk atau istirahat sejenak sebelum naik ke kampung atau istirahat sebelum melanjutkan perjalanan, sambil menikmati keindahan bunga atau sekedar berswafoto.

Peta pariwisata (tourist map) terletak di dekat pintu gerbang Kampung Adat Prai Ijing. Peta pariwisata Kampung Adat Prai Ijing berisi rute perjalanan wisatawan untuk mengelilingi kampung, jumlah rumah adat, letak kubur batu dan 
hal-hal yang dilarang atau tidak boleh dilakukan di sekitar rumah adat dan kubur batu.

Salah satu upaya yang dilakukan oleh pemerintah desa dan pihak pengelola untuk memberikan kenyamanan bagi wisatawan di Kampung Adat Prai Ijing disediakan empat unit toilet, satu unit toilet terletak di dekat loket tiket dan tiga unit toilet berada di dekat pintu masuk kampung.

Gazebo terletak di atas bukit Prai Ijing, beratap alang, terdapat beberapa kursi dan meja. Fasilitas ini disediakan bagi wisatawan yang ingin sekedar duduk beristirahat sambil menikmati sejuknya udara dan pemandangan di sekitar Kampung Adat Prai Ijing dari atas bukit Prai Ijing setelah mengelilingi kampung, menikmati atraksi dan aktivitas di Kampung Adat Prai Ijing, serta berswafoto di spot foto yang disediakan.

Kios cinderamata menjual barangbarang kerajinan khas Kampung Adat Prai Ijing seperti kain tenun khas Sumba Barat, selendang, tas anyam, dompet, dan cinderamata lainnya. Cinderamata ini merupakan hasil keterampilan dari masyarakat kampung yang masih dikelola secara pribadi, jumlahnya masih terbatas atau tidak diproduksi secara massal. Saat ini Bumdes Iyya Tekki bersama masyarakat setempat sedang mempersiapkan galeri cinderamata yang menyediakan berbagai macam cinderamata, seperti kain tenun, tas daun pandan, dompet, gelas bambu, gantungan kunci dan mangkok dari tempurung kelapa, kalung parang terbuat dari tanduk kerbau, mamuli/hiasan terbuat dari tanduk kerbau, tas manik, topi, dan camilan-camilan khas Kampung Adat Prai Ijing. Bagi wisatawan yang berminat dapat membeli cinderamata untuk dibawa pulang ke daerah atau negara asalnya.

\section{d. Lembaga Pengelola (Ancillary)}

Pada awal pengembangannya Kampung Adat Prai Ijing dikelola secara mandiri atas inisiasi beberapa pemuda kampung. Wisatawan tidak dikenakan tiket masuk hanya diminta mengisi buku tamu dan memberikan donasi atau sumbangan seikhlasnya. Hingga tahun 2012 jumlah kunjungan wisatawan semakin meningkat. Partisipasi masyarakat Kampung Adat Prai Ijing yang dilibatkan menjadi pelaku pariwisata semakin ditingkatkan. Hasil dari donasi yang diberikan wisatawan digunakan untuk biaya operasional dan pelestarian Kampung Adat Prai Ijing. Selama kurang lebih enam tahun dikelola secara mandiri dengan melihat potensi wisata, keseriusan masyarakat, serta semakin meningkatnya jumlah kunjungan wisatawan Pemerintah Desa melalui Kepala Desa Marthen Ragowino Bira, SS yang merupakan salah satu inisiator pengembangan Kampung Adat Prai Ijing kemudian menggagas Kampung Adat Prai Ijing dikelola secara profesional.

Pada Bulan Juli 2018 bersamaan ditetapkannya Kampung Adat Prai Ijing sebagai daya tarik wisata berdasarkan Perdes Tebara No. 02 Tahun 2018 Pemerintah Desa juga resmi membentuk lembaga pengelola Kampung Adat Prai Ijing yaitu Badan Usaha Milik Desa Iyya Tekki dan Kelompok Sadar Wisata (Pokdarwis).

Berdasarkan Keputusan Kepala Desa Nomor 02 /TBR/KEP/I/2018 tentang Penetapan Kepengurusan Badan Usaha Milik Desa Iyya Tekki Desa Tebara Kecamatan Kota Waikabubak Tahun Anggaran 2018. Tugas Pengurus Badan Usaha Milik Desa (Bumdes) Iyya Tekki yang dilaksanakan oleh Pelaksana Operasional antara lain, memimpin dan mengendalikan semua kegiatan Bumdes 
Iyya Tekki; Merencanakan dan menyusun program kerja; Membina pegawai; Mengurus dan mengelola Bumdes Iyya Tekki; Menyelenggarakan administrasi umum dan keuangan; Melaksanakan Kegiatan Teknis Bumdes Iyya Tekki; Menyampaikan laporan berkala mengenai seluruh kegiatan termasuk neraca dan perhitungan rugi/laba. Pengurus mendapatkan penghasilan berupa gaji atau upah dan diberikan penghasilan tetap lainnya sesuai dengan kemampuan Bumdes Iyya Tekki.

Peraturan Desa Nomor 04 / TBR / 53.12 / 2018 tentang Badan Usaha Milik Desa Iyya Tekki. Dalam menjalankan usaha ekonomi desa secara maksimal, Bumdes Iyya Tekki terdiri dari unit usaha yang mengelola jenis usaha sesuai hasil pembahasan dan kesepakatan dalam musyawarah desa. Susunan kepengurusan Bumdes Iyya Tekki terdiri dari penasihat, pelaksana operasional dan pengawas. Tugas dan tanggung jawab dari susunan kepengurusan dibahas dan disepakati dalam musyawarah desa yang diselenggarakan oleh BPD yang menjadi bagian dari anggaran dasar dan anggaran rumah tangga bumdes yang ditetapkan dengan keputusan Kepala Desa. Modal bumdes terdiri atas penyertaan modal desa dan penyertaan modal masyarakat desa yang berasal dari APBD dengan menggunakan dana desa sebesar $80 \%$ dan berasal dari kelompok masyarakat desa sebesar 20\% sesuai hasil pembahasan dan kesepakatan dalam Musyawarah Desa.

Bumdes Iyya Tekki menjalankan usaha ekonomi desa dengan memanfaatkan sumber daya di desa; Potensi pasar sarana produksi pertanian; Jasa produksi pertanian meliputi olah lahan, pembibitan, tanam, panen, penampungan hasil pertanian, dan penanganan pasca panen; Pengolahan dan pemasaran hasil pertanian; Potensi pariwisata budaya dan alam.

Dalam menjalankan usaha ekonomi desa secara maksimal bagi masyarakat desa, Bumdes membentuk unit usaha:

a. Jasa produksi atau perdagangan meliputi: kantor, gudang; Pengadaan pupuk organik dan anorganik; Toko desa sembako/material (grosir); Penggilingan padi (giling keliling); Bisnis ternak besar (kerbau, sapi, kuda, babi).

b. Bisnis Bersama meliputi, Desa/Kampung Wisata Prai Ijing; Kolam wisata/pemandian atau danau Wisata Weeboro; Pasar desa.

c. Bisnis sosial (air minum desa dan lumbung pangan) meliputi kantor dan gudang; mesin pengolahan; Manajemen operasional.

d. Bisnis keuangan atau usaha simpan pinjam.

e. Bisnis Penyewaan berupa penyediaan alat atau perkakas pesta. Pengelolaan Kampung Adat Prai Ijing, dikelola langsung oleh Bumdes Iyya Tekki melalui unit usaha bisnis bersama dan dalam pengembangannya bekerjasama dengan Kelompok Sadar Wisata (Pokdarwis) Desa Tebara. Pengurus Lembaga Desa Wisata/Kelompok Sadar Wisata (Pokdarwis) mempunyai tugas dan tanggung jawab sebagai berikut:

a. Menyiapkan data dan informasi tentang keadaan maupun perkembangan berbagai kegiatan yang berkaitan dengan pengelolaan Kepariwisataan di Desa Tebara.

b. Menyampaikan berbagai data, informasi dan masalah kepada instansi atau lembaga terkait untuk penyelesaian tindak lanjut. 
c. Menganalisa masalah dan kebutuhan intervensi program berdasarkan pilihan alternatif pemecahan masalah sesuai dengan potensi dan kebutuhan lokal.

d. Menyusun rencana kegiatan tahunan dan mengupayakan adanya sumber - sumber pendanaan untuk mendukung kegiatan Pengembangan Desa Wisata.

e. Melakukan bimbingan, pembinaan, fasilitasi, advokasi, pemantauan dan evaluasi pengelolaan program atau kegiatan Desa Wisata/Sadar Wisata secara rutin dan terjadwal.

f. Memfasilitasi penggerakan dan pengembangan partisipasi gotong royong, dan swadaya masyarakat dalam mengembangkan Kepariwisataan.

\section{PENUTUP}

Kampung Adat Prai Ijing terletak di Dusun Prai Ijing Desa Tebara, Kecamatan Kota Waikabubak, Kabupaten Sumba Barat, Provinsi Nusa Tenggara Timur (NTT). Kampung Adat Prai Ijing merupakan salah satu destinasi wisata potensial dengan hamparan batu kubur megalitikum dan rumah adat tradisional didalamnya serta memiliki budaya yang unik, lokasi strategis, serta ramai dikunjungi wisatawan. Pengembangan pariwisata dikelola oleh Bumdes Iyya Tekki dan seluruh masyarakat desa. Pengembangan tersebut mampu memberikan tambahan penghasilan bagi masyarakat lokal. Ada upaya untuk meningkatkan kualitas sumber daya manusia dengan pelatihan keterampilan dan Bahasa Inggris. Terdapat komponen pariwisata dalam menunjang pengembangan pari- wisata yaitu atraksi, aksesibilitas, amenitas, dan adanya lembaga pengelola (ancillary). Sebagai masukan untuk pengembangan selanjutnya perlu mempertahankan kelestarian budaya dan kearifan lokal, meningkatkan kualitas pelayanan, keragaman atraksi dan aktivitas wisata di Kampung Adat Prai Ijing.

\section{DAFTAR PUSTAKA}

Anonim. Undang-undang Republik Indonesia No.10 Tahun 2009 tentang Kepariwisataan.

, Keputusan Kepala Desa Nomor 02 /TBR/KEP/I/2018 tentang Penetapan Kepengurusan Badan Usaha Milik Desa Iyya Tekki Desa Tebara Kecamatan Kota Waikabubak Tahun Anggaran 2018.

, Keputusan Kepala Desa No 02 Tahun 2018 tentang Penetapan Pengurus dan Struktur Organisasi Badan Usaha Milik Desa Iyya Tekki Masa Bakti 2018 2021.

, Peraturan Desa Tebara No. 04/TBR/53.12/2018 tentang Badan Usaha

Milik Desa Iyya Tekki.

Ardika, I Wayan. 2007. Pusaka Budaya dan Pariwisata. Denpasar: Pustaka Larasan.

Fitriyani, A. 2016. "Etnofarmasi dan Saintifikasi Tumbuhan yang Digunakan pada

Masa Kehamilan dan Pasca Melahirkan di Tiga Kampung Adat yang Berada di Wilayah Bandung" (tesis). Bandung: Fakultas MIPA (UNISBA). 
Kusmayadi dan Sugiarto, E. 2000.

Metodologi Penelitian Dalam Bidang

Kepariwisataan. Jakarta: PT Gramedia

Pustaka Utama.

Suwantoro, G.2002. Dasar-dasar

Pariwisata. Yogyakarta: ANDI.

Suwena, I Ketut dan I Gst Ngr Widyatmaja. 2010. Pengetahuan Dasar Ilmu Pariwisata. Denpasar: Udayana University Press.

Yoeti, O.A. 1996. Pengantar Ilmu Pariwisata . Bandung:Angkasa.

2006. Pariwisata Budaya,

Masalah, dan Solusinya. Jakarta: PT. Pradnya Paramita.

\section{PROFIL PENULIS}

Fatrisia Yulianie, lahir di Palangkaraya, 22 Juli 1985. Menyelesaikan pendidikan Diploma IV (D4) Pariwisata di Fakultas Pariwisata Universitas Udayana tahun 2007. Program Kajian Pariwisata Universitas Udayana tahun 2015. Penulis memiliki pengalaman sebagai tenaga pengajar di Akadami Pariwisata Kupang dan saat ini telah menjadi dosen tetap di Institut Pariwisata dan Bisnis Internasional.

Fransiska Fila Hidayana, lahir di Palangkaraya, 2 Oktober 1988. Menyelesaikan pendidikan Diploma IV (D4) Pariwisata di Fakultas Pariwisata Universitas Udayana tahun 2010. Program Magister Pariwisata tahun 2019. Pengalaman yang dimiliki adalah bekerja selama enam tahun di biro perjalanan wisata sebagai frontliner ticketing dan supervisor. Saat ini penulis bekerja sebagai dosen tetap di Akademi Pariwisata Denpasar. 